\title{
Evaluasi Berperspektif Orisinalitas Jenis Kayu Terhadap Pemugaran Cagar Budaya Bangunan Alang Pertama Sebagai Komponen Rumah Adat Tana Toraja Pada Situs Nanggala
}

\author{
Yustinus Suranto \\ Fakultas Kehutanan Universitas Gadjah Mada, Jl. Agro, Bulaksumur, Yogjakarta 55281 \\ E-mail: surantoyustinus@yahoo.com
}

\begin{abstract}
Abstrak: Alang dan Tongkonan merupakan bangunan penyusun Rumah Adat Tana Toraja berstatus Bangunan Cagar Budaya Berbahan Kayu (BCBBK). Bersama keunikan budaya dan keindahan bentang alam, BCBBK menempatkan Tana Toraja sebagai tujuan wisata dunia dan diusulkan sebagai peninggalan dunia (world heritage). Undang-undang Cagar Budaya mengamanatkan pelestarian BCBBK dengan aktivitas: pemeliharaan, perawatan, konservasi dan pemugaran secara arkeologis, yakni mempertahankan keaslian: bahan, teknologi pengerjaan, bentuk-ukuran-desain, arsitektur, budaya dan situs. Alang pertama Situs Nanggala baru saja dipugar oleh masyarakat pemiliknya. Penelitian bertujuan mengevaluasi penerapan prinsip arkeologis pada pemugaran dari perspektif konservasi jenis kayu.

Objek penelitian berupa Alang pertama Situs Nanggala kawasan Tana Toraja. Metode penelitian meliputi: (1) pengamatan bangunan alang hasil pemugaran, (2) pengambilan sampel kayu arkeologis bekas komponen alang dan sampel kayu baru penggantinya, (3) mengidentifikasi untuk menentukan jenis kayu arkeologis dan kayu baru, (4) mengkomparasikan jenis kayu baru terhadap jenis kayu arkeologis, (5) mengevaluasi penerapan prinsip arkeologis, khususnya orisinalitas jenis bahan.

Hasil penelitian menyimpulkan tiga hal. Pertama, seluruh komponen struktural dan non-struktural alang telah diganti kayu (bahan) baru. Kedua, identifikasi kayu arkeologis dan kayu baru secara berurutan menghasilkan jenis kayu: (a) wanga (Pigafetta filifera Merr) dan wanga bagi tiang, (b) cemara gunung (Casuarina Junghubniana) dan cemara gunung bagi balok/belandar, (c) uru (Elmerrillia ovalis Dandy) dan tusam (Pinus merkusii Junghuh et de Vries) bagi papan lantai (d) uru dan sengon (Paraserianthes falcataria (L) Nielson) bagi papan dinding, (e) bambu dan seng gelombang bagi penutup atap. Ketiga, pemugaran alang pertama dilakukan tanpa ketaatan penerapan prinsip arkeologis, khususnya orisinalitas jenis bahan.
\end{abstract}

Kata kunci: Identifikasi, Kayu, Evaluasi, Pemugaran, Alang, Nanggala.

\begin{abstract}
Alang and Tongkonan are two kinds of unique building compilers Tana Toraja traditional house's status as a Wooden Cultural Heritages (WCH). WHC with it's unique social and cultural conditions and beautiful landscapes have made it to became world tourist site, and nominate to be inscribed as World Heritage. Indonesian Law Number 11 Year 2010 regarding Cultural Heritage mandates WCH to be preserved through:. preservation maintenance, conservation and restoration using archaeological perspective, by maintaining the originality of: materials, workmanship, size-shape-design, architecture, culture and sites. As part of Tana Toraja, The first Alang of Nanggala site has undergone restoration by community. The study is aimed to evaluate whether Alang restoration was done by the application of archaeological principles, particularly on the perspective of timber conservation.

Object of the study is the first Alang of Nenggala site. Methods of study includes: (1) observation on the restorated Alang, (2) taking sample of archaeological wood and new wood on each building component (3) microtomic section to get tranversal cut and its microscopic portrait and identifing tipe of both archaeological and nw wood based on macroscopic structural image (4) comparing the wood species of new wood spesies and archaeological one functioning the same building component (5) evaluate the level of adherence to the application of the archaeological principles, particularly on material originality.

The result concludes three things. First, all structural and non-structural Alang components replaced by new wood (material). Second, identification of an archaelogical wood and a new wood produces a sequence of timber as follows: (a) wanga (Pigafetta filifera Merr) and also wanga for pillar components, (b) mountain pine (Casuarina Junghubniana Miq) and also mountain pine for the beam components, (c) uru (Elmerrillia ovalis Dandy) and pine (Pinus merkusii Junghuh et de Vries) for the plank flooring (d) uru and sengon (Paraserianthes falcataria Nielson) for wallboard componen, (e) bamboo and corrugated iron sheets for roofing components. Thirdly, Alang restoration was done without fully compliance on the application of archaeological principles, especially the materials originality.
\end{abstract}

Keywords: Wood Identification, Alang restoration evaluation, Nanggala site.

\section{Pendahuluan}

Bangsa Indonesia memiliki banyak benda dan bangunan cagar budaya yang tersebar di seluruh wilayah kepulauan Negara Kesatuan Republik Indonesia, baik di wilayah perairan maupun daratan. Setiap benda dan bangunan cagar budaya memiliki keunikan, kekhasan 
dan kekhususan dalam hal bahan, wujud, bentuk, periode waktu pembuatan serta latar belakang etnik dan budaya leluhur pembuat benda dan bangunan tersebut. Benda dan bangunan cagar budaya itu pada umumnya berada di dalam suatu situs atau bahkan kawasan yang memiliki bentang alam yang sangat unik dan khas serta indah, sehingga secara keseluruhan membentuk suatu kesatuan situs atau bahkan kesatuan kawasan cagar budaya. Salah satu kawasan cagar budaya yang telah berstatus sebagai tujuan wisata nusantara maupun wisata dunia adalah kawasan permukiman tradisional etnik Tana Toraja.

Kawasan permukiman tradisional etnik Tana Toraja sebagai kawasan cagar budaya mencakup banyak situs, satu diantaranya adalah Situs Nanggala. Sebagaimana permukiman tradisional Tana Toraja pada umumnya yang terdiri atas tongkonan dan alang, permukiman tradisional situs Nanggala juga demikian halnya, yaitu terdiri atas Rumah Adat Tongkonan dan Alang. Pada salah satu alang di Situs Nenggala telah dilakukan pemugaran dan diselesaikan pada akhir tahun 2009. Pemugaran ini dilakukan oleh satu keluarga yang menjadi anggota keluarga besar pemilik Situs Nanggala tersebut.

Mengingat bahwa Situs Nanggala merupakan kawasan cagar budaya, maka pemugaran wajib dilakukan dengan mengikuti aturan perundangan yang menerapkan prinsip-prinsip arkeologis, antara lain menjaga orisinalitas dalam hal bahan. Penelitian ini dilakukan dengan maksud untuk mengevaluasi apakah prinsip-prinsip orisinalitas dijadikan dasar dalam pelaksanaan pemugaran tersebut khususnya dari perspektif orisinalitas bahan kayu atau konservasi jenis kayu. Dengan penelitian ini diharapkan dapat mengungkap dua hal; pertama, mengetahui jenis kayu arkeologis dan kayu baru sebagai komponen bangunan alang yang pertama; kedua, mengevaluasi apakah prinsip orisinalitas bahan diterapkan di dalam pemugaran bangunan alang.

\section{Tinjauan Pustaka}

\subsection{Tana Toraja sebagai Kawasan Cagar Budaya dan Destinasi Wisata.}

Indonesia merupakan negara maritim yang menempati wilayah sangat luas dan memiliki keragaman yang sangat besar, baik keragaman kondisi geografis pada setiap kawasan, keragaman kondisi pulau yang ada pada setiap kawasan itu, maupun keragaman etnis yang menempati setiap pulau serta keragaman adat-istiadat dan kebudayaan setiap etnis. Tingkat keragaman yang tinggi itu disebabkan oleh begitu banyaknya jumlah etnis yang menjadi bagian tak terpisahkan sebagai komponen penyusun bangsa Indonesia, sedangkan masing-masing etnis memiliki keunikan dan kekhasannya tersendiri terkait dengan adat istiadat dan kebudayaannya.

Dengan kekhasan adatistiadat dan kebudayaannya itu, setiap etnis memiliki kemampuan untuk menciptakan benda dan bangunan yang unggul dan unik yang kemudian ditetapkan oleh Pemerintah sebagai cagar budaya. Oleh karena itu, setiap benda dan bangunan cagar budaya memiliki keunikan, kekhasan, dan kekhususan baik dalam hal bahan, wujud, bentuk, periode waktu pembuatan serta latar belakang etnik dan budaya leluhur pembuat benda dan bangunan cagar budaya. Dengan demikian, Bangsa Indonesia memiliki banyak benda dan bangunan cagar budaya yang tersebar di seluruh wilayah kepulauan Negara Kesatuan Republik Indonesia, baik yang ada di wilayah perairan maupun di daratan.

Keberadaan benda dan bangunan cagar budaya merupakan bukti nyata atas sikap hidup dan mentalitas tertentu yang dimiliki oleh para komunitas leluhur etnis pembangun benda dan bangunan cagar budaya tersebut. Dengan kata lain, benda dan bangunan cagar budaya mengandung sikap hidup dan mentalitas unggul yang dimiliki oleh para anggota komunitas leluhur pendirinya. Sikap hidup dan mentalitas itu berupa sikap hidup yang penuh dengan nilai-nilai: keluhuran, ketekunan, kerjasama, kebersamaan, kegigihan, kerajinan, semangat kerja, pengorbanan, dan nilai-nilai luhur budaya lainnya sebagai kearifan lokal dalam beradaptasi terhadap lingkungan alam tempat hidupnya.

Oleh karena itu, benda dan bangunan cagar budaya diharapkan menjadi sumberdaya mental yang dapat memberi inspirasi dan sumber pembelajaran bagi setiap generasi penerus bangsa Indonesia (Mundardjito, dalam Akbar 2010). Setiap orangyang hidup sebagai generasi baru dan generasi penerus diharapkan dapat belajar mengenai mentalitas dan sikap hidup serta nilai-nilai luhur budaya tersebut ketika dirinya berkunjung pada bangunan cagar budaya (BCB). Dengan demikian, aktivitas berkunjung dan berwisata di dalam situs bangunan cagar budaya diharapkan dapat menjadi wahana pendidikan dalam rangka menanamkan dan menumbuhkan mentalitas 
unggul dan sikap hidup bernilai luhur.

Mengingat akan tingginya nilai-nilai yang terkandung di dalam cagar budaya, maka Bangsa Indonesia sadar akan kewajiban untuk menjaga kelestarian dan keasliannya. Kewajiban demikian tertuang dalam Undang-Undang Negara Republik Indonesia No. 11 Tahun 2010 tentang Cagar Budaya. Undang-undang ini mengamanatkan, bahwa cagar budaya wajib dilestarikan melalui kegiatan pemeliharaan, perawatan, konservasi maupun pemugaran. Untuk menjaga keasliannya, maka pemugaran wajib dilakukan dengan mematuhi prinsipprinsip arkeologis, yakni mempertahankan keaslian dalam hal: bahan, teknologi pengerjaan, bentuk-ukuran-desain, arsitektur dan budaya maupun situs (Presiden Republik Indonesia, 2010).

Salah satu kawasan cagar budaya yang sangat penting di Indonesia adalah kawasan yang menjadi tempat bermukim bagi etnis Tana Toraja. Kawasan ini luasnya sekitar $3205 \mathrm{~km}^{2}$. Secara geografis, etnis TanaToraja menempati kawasan yang relatif berbukit dengan dataran tinggi yang ketinggiannya berkisar antara 300 sampai dengan 2800 meter di atas permukaan laut. Secara administratif, kawasan ini berada di dua kabupaten, yakni Tana Toraja dan Toraja Utara, Provinsi Sulawesi Selatan (Anonim, 2009).

Permukiman ini berupa rumah adat yang terdiri atas Bangunan Tongkonan dan Alang (BTA). BTA merupakan Bangunan Cagar Budaya Berbahan Kayu (BCBBK) yang atapnya berbahan bambu dan ijuk (Anonim, 2011). BTA ini tersebar pada banyak situs. Bersama dengan kondisi sosial budayanya yang unik dan kondisi bentang alam pegunungannya yang indah dan asri, BTA Tana Toraja telah membentuk suatu kawasan yang menjadi tujuan utama bagi wisatawan nusantara maupun dunia (Inajati, 2009).

Permukiman Tradisional Tana Toraja bahkan telah diusulkan oleh Pemerintah Indonesia, yang dalam hal ini diwakili oleh Kementerian Kebudayaan dan Pariwisata Republik Indonesia, kepada UNESCO agar badan dunia ini menetapkan kawasan permukiman Tana Toraja berstatus sebagai peninggalan dunia (world heritage). UNESCO telah menerima usulan itu pada hari Selasa, 6 Oktober 2009 dan menominasikannya sebagai salah satu warisan dunia. Permukiman tradisional yang diterima untuk dinominasikan sebagai warisan dunia ini terdiri atas serangkaian 10 situs permukiman tradisional beserta konstituennya (Anonim, 2009).

Secara tradisional, sebuah permukiman Toraja terdiri dari tujuh komponen, yaitu rumah (tongkonan) dan lumbung (alang), tempat penguburan (liang), lapangan upacara yang ditandai dengan adanya menhir (rante), sawah, hutan bambu, dan tanah penggembalaan atau padang rumput untuk penyediaan makanan bagi hewan peliharaan, terutama kerbau dan babi. Meskipun demikian, tidak setiap situs yang dinominasikan itu memiliki ketujuh komponen permukiman tersebut secara lengkap. Hal ini disebabkan oleh adanya dinamika dan perubahan perkembangan lingkungan alam dan lingkungan sosial yang terjadi pada setiap situs (Anonim, 2009).

Sepuluh situs permukiman tradisional yang diterima dan dinominasikan oleh UNESCO sebagai peninggalan dunia itu meliputi situs-situs: (1) Pallawa, (2) Bori Parinding, (3) Kande Api, (4) Nanggala, (5a) Buntu Pune, (5b) Rante Karassik, (6) Ke'te Kesu', (7) Pala' Toke', (8) Londa, (9) Lemo, dan (10) Tumake (Anonim, 2009).

Di dalam keragaman yang ada pada etnik Tana Toraja itu, Situs Nanggala dipilih sebagai objek kajian. Pemilihan ini didasarkan pada dua pertimbangan. Pertama, Situs Nanggala menjadi salah satu diantara 10 situs yang dinominasikan oleh UNESCO sebagai warisan dunia. Kedua, telah terselesaikannya aktivitas pemugaran pada salah satu alang yang menjadi komponen bangunan cagar budaya berbahan kayu pada Situs Nanggala.

\subsection{Struktur Bangunan Alang.}

Alang dan tongkonan merupakan dua jenis bangunan berbahan kayu yang memiliki bentuk arsitektur serupa tetapi ukurannya berbeda, yakni alang lebih kecil daripada tongkonan. Keduanya merupakan pasangan penyusun komponen rumah adat Tana Toraja. Berdasarkan strukturnya, bangunan alang dapat dibagi menjadi tiga bagian, yaitu bagian kolong, bagian badan dan bagian kepala atau atap (Anonim, 2011). Komponen bangunan penyusun masing-masing bagian itu disajikan sebagai berikut (Gambar 1-4).

Pada bagian kolong alang terdapat lima macam komponen bangunan, yaitu pondasi, tiang (kolom), balok, lantai dan tangga. Pondasi berupa batu yang keras dan 
diletakkan secara bebas di atas tanah. Pondasi menjadi tumpuan bagi tiang (kolom). Komponen kedua adalah tiang. Tiang memiliki bentuk silinder dengan penampang melintang yang bulat dan berasal dari potongan batang tetumbuhan keluarga palmae. Komponen ketiga pada kolong Alang adalah balok. Balok berfungsi sebagai pengikat antar kolom. Dengan demikian, balok akan berfungsi sebagai sloof. Dengan adanya balok ini, maka pergeseran yang mungkin terjadi antara tiang dengan pondasi dapat dicegah. Hubungan antara balok dengan kolom diperkuat dengan menggunakan sambungan pasak. Jumlah balok pada alang hanya satu saja, yaitu sebagai pengikat pada bagian bawah kolom. Komponen keempat pada kolong alang adalah lantai. Lantai alang terbuat dari papan kayu yang disusun di atas balok. Komponen kelima kolong alang adalah tangga. Tangga digunakan sebagai sarana untuk menaikkan padi dan memasukkannya ke

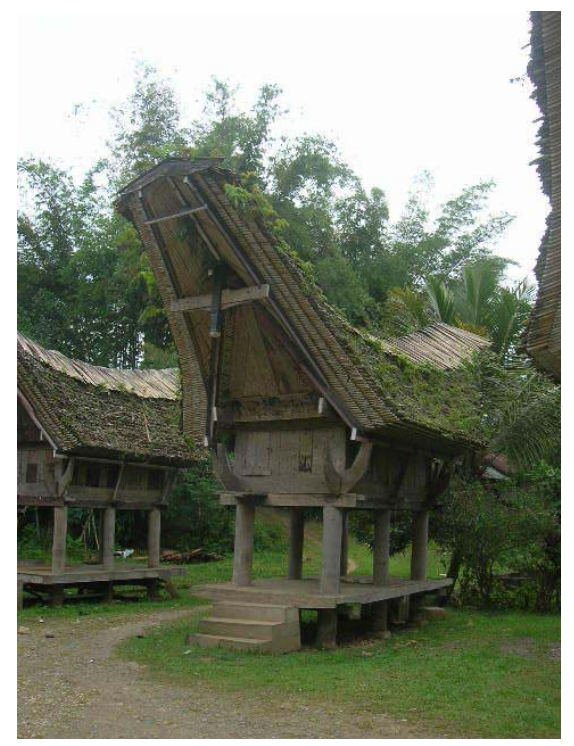

Gambar 1. Alang (secara perspektif)

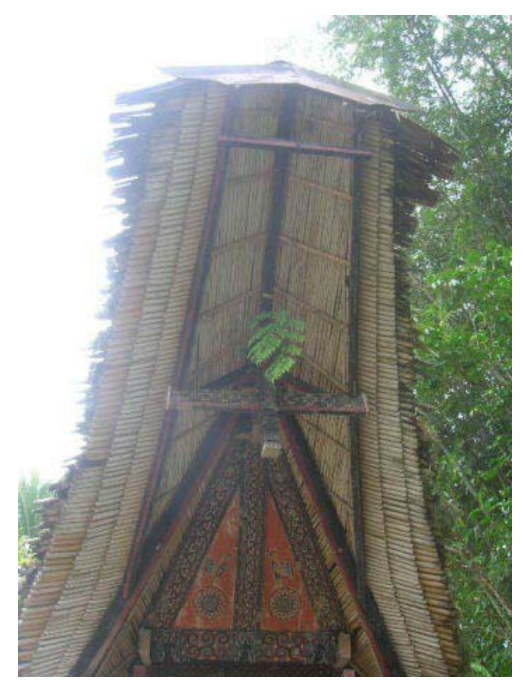

Gambar 3. Atap Alang (tampak depan) dalam badan alang dalam rangka menyimpannya. Tangga juga digunakan sebagai sarana untuk menurunkan padi ke luar dari badan alang, setelah cukup lama padi itu disimpan di dalam badan alang. Tangga dikonsruksikan secara tidak permanen, yakni dapat dipasang dan dilepas kembali sesuai dengan fungsi sesaatnya untuk menaikkan atau menurunkan padi (Anonim, 2011).

Pada badan sebagai bagian kedua dari alang terdapat tiga macam komponen bangunan, yaitu lantai, dinding, dan pintu atau jendela. Lantai alang terbuat dari papan kayu yang disusun di atas susunan balok lantai. Penyusunan lantai dilakukan dengan arah memanjang sejajar balok utama. Dinding alang terdiri atas dua komponen, yaitu rangka dinding dan pengisi dinding atau papan dinding. Kedua komponen dinding ini berbahan kayu. Pengisi dinding terdiri atas papan-papan kayu yang disusun dengan sambungan alur dan lidah pada sisi-sisi

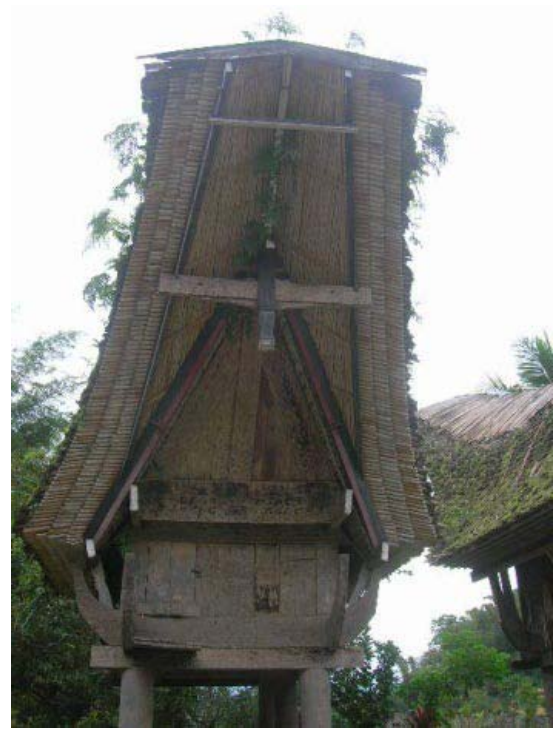

Gambar 2. Alang (tampak depan)

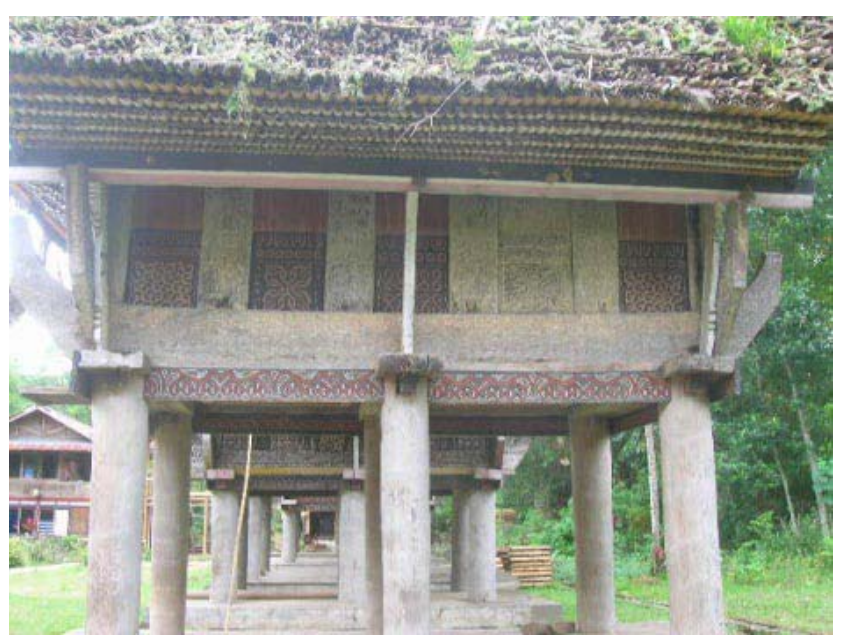

Gambar 4. Atap Alang (tampak samping kanan) 
panjang papan dengan ikatan utama yang dinamakan Sambo Rinding (Anonim, 2011).

Bagian kepala terdiri atas atap yang bentuknya khas, yakni menjulur panjang ke arah bagian depan dan belakang alang, sedemikian rupa sehingga atap keseluruhan membentuk lengkungan parabolik. Atap alang terbuat dari bambu yang dibelah dan disusun secara tumpang tindih. Belahan bambu disatukan oleh beberapa reng bambu dan diikat dengan tali yang terbuat dari bambu atau rotan. Di atas atap bambu ini diberi lapisan yang terbuat dari ijuk (Anonim, 2011).

\subsection{Identifikasi Kayu}

Identifikasi kayu merupakan aktivitas untuk menentukan jenis kayu. Penentuan jenis kayu dilakukan melalui mengamatan terhadap struktur makroskopis kayu dan tekstur kayu. Pengamatan struktur kayu diarahkan untuk mengenal komponen-komponen seluler penyusun kayu, yang meliputi serabut, trakeid, pembuluh, jari-jari, parenkim, dan saluran damar. Struktur kayu mempelajari tentang keberadaan, posisi dan konfigurasi komponen sel-sel penyusun kayu. Secara makroskopis, konfigurasi ini membentuk lingkaran pertumbuhan, kayu gubalkayu teras, kayu awal-kayu akhir, serta pola-pola tertentu yang secara khas menampilkan wajah kayu. Tekstur kayu merupakan terminologi yang berkait dengan dimensi komponen sel-sel penyusun kayu. Berdasarkan dimensi itu, tekstur membedakan kayu bertekstur halus, sedang dan kasar (Soenardi, 1977).

Ilmu struktur kayu juga mempelajari keanekaan atau keragaman konfigurasi yang terbentuk oleh jaringanjaringan komponen penyusun kayu tersebut. Konfigurasi jaringan-jaringan ini membentuk pola tertentu. Pola tertentu ini berkait dengan unsur genetis jenis kayu, sehingga jenis kayu tertentu akan memiliki pola tertentu. Oleh karena itu, setiap konfigurasi itu dapat dijadikan dasar untuk menentukan jenis kayu, karena setiap jenis kayu memiliki konfigurasi jaringan kayu yang unik dan spesifik. Hal ini berarti bahwa konfigurasi tertentu atas jaringan-jaringan tersebut hanya dimiliki oleh jenis kayu tertentu pula. Dengan demikian, pola konfigurasi jaringan-jaringan sel penyusun kayu dapat dijadikan dasar untuk mengidentifikasi jenis kayu (Soenardi, 1977).

\section{Bahan dan Metode}

Bahan yang diposisikan sebagai objek penelitian adalah alang yang telah selesai dipugar, yakni alang nomor satu. Alang nomor satu bersama dengan 15 unit alang lainnya dan dua unit tongkonan merupakan komponen penyusun Perkampungan Rumah Adat Tana Toraja Situs Nanggala, Kabupaten Toraja Utara, Provinsi Sulawesi Selatan.

Metode penelitian secara garis besar terdiri atas dua tahap, yaitu pengamatan secara in-situ dan exsitu. Pengamatan secara in-situ dilakukan terhadap setiap komponen penyusun alang nomor satu hasil pemugaran, baik komponen struktur (tiang dan balok) maupun nonstruktur (papan lantai dan papan dinding) bangunan. Pengamatan dilanjutkan dengan pengambilan sample kayu baru dari setiap komponen bangunan alang tersebut. Pengambilan sampel kayu juga dilakukan terhadap kayu arkeologis atau kayu lama dari setiap komponen bangunan alang nomor satu ini sebelum alang tersebut dipugar, sehingga kayu arkeologis ini berupa limbah kayu. Pengambilan sampel kayu baru maupun kayu arkeologis dilakukan dengan pemanduan dan bantuan dari pemilik alang nomor satu tersebut. Pengambilan sampel ini ditindaklanjuti dengan pemberian label pada masing-masing sampel tersebut. Pengamatan in-situ juga dilakukan terhadap komponen flora dan fauna serta situs permukiman tersebut.

Sementara itu, proses pengamatan secara $e x-$ situ dilakukan dengan dua langkah aktivitas, yaitu (1) identifikasi jenis kayu, baik kayu baru maupun kayu arkeologis, (2) membandingkan antara jenis kayu baru dan jenis kayu arkeologis sebagai penyusun komponen yang sama pada bangunan alang. Proses pengamatan exsitu dilakukan di Bagian Teknologi Hasil Hutan, Fakultas Kehutanan Universitas Gadjah Mada, Yogyakarta. Pencuplikan untuk mengambil sampel kayu dilakukan dengan menggunakan beberapa peralatan, antara lain: gergaji potong, tatah, parang, pukul besi, kantong plastik, dan kertas label

Metode penelitian secara detil dalam rangka mengidentifikasi jenis kayu dilakukan dengan prosedur sebagai berikut.

1. Sampel kayu diiris dengan menggunakan mikrotom model 860 buatan American Optical Corporation USA untuk mendapatkan penampang transversal. 
Penampang transversal dipotret secara makroskopis dengan menggunakan mikroskop Olympus BX51. Gambar yang dihasilkannya diamati komponen struktur makroskopis, yang meliputi keberadaan lingkaran tahun, persebaran dan susunan pembuluh, bentuk dan pola jaringan parenkim, dimensi dan keberagaman jari-jari, keberadaan saluran damar dan tekstur kayu. Di samping itu, diamati pula arah serat pada penampang tangensial.

2. Berdasarkan deskripsi struktur makroskopis dan tekstur kayu, dilakukan proses identifikasi dan determinasi untuk menentukan jenis kayu.

3. Mengkonfirmasi hasil identifikasi yang dilakukan dengan membandingkannya dengan jenis-jenis kayu yang tersaji di dalam berbagai sumber pustaka, agar hasil identifikasi dapat dijamin dan dipastikan kebenarannya.

Secara keseluruhan, penelitian ini memerlukan waktu 14 hari. Aktivitas penelitian selama durasi waktu tersebut terbagi dua bagian. Pertama, aktivitas pengamatan dan pengambilan contoh uji selama 8 hari, yakni Senin, 20 s.d Senin, 27 Juni 2011. Kedua, proses identifikasi kayu dilakukan selama 6 hari.

\section{Hasil dan Pembahasan}

\subsection{Hasil Pengamatan in-situ}

Pengamatan secara in-situ terhadap Bangunan Tongkonan Alang Situs Nanggala mendapatkan empat realitas berikut. Pertama, Situs Nanggala terdiri atas perpaduan antara dua unit tongkonan dan enam belas unit alang. Tongkonan dan alang diatur secara selaras dalam posisi berjajar pada arah timur barat, sehingga tongkonan dan alang itu masing-masing terletak di bagian selatan dan bagian utara suatu kompleks permukiman. Keduanya saling berhadapan, karena tongkonan menghadap ke arah utara sedangkan alang menghadap ke arah selatan. Antara deretan tongkonan dan deretan alang ini terdapat ruang terbuka yang digunakan untuk menjemur padi, pertemuan keluarga dan interaksi sosial. Permukiman ini dikelilingi oleh tembok batu yang rendah dengan pintu masuk yang berada pada sisi barat daya. Di sebelah timur permukiman terdapat tanah seremonial (rante) dan kuburan. Pada kuburan ini ditempatkan beberapa rumah peti kayu (patane).

Kedua, bangunan tongkonan yang berjumlah dua unit itu terbuat dari bahan yang sama, yaitu bagian kaki dan badannya terbuat dari kayu dan bagian atapnya terbuat dari bambu. Meskipun demikian, ada pula perbedaan di antara keduanya tentang bahan pembuat penutup atap, yakni penutup atap pada tongkonan pertama berbahan dasar bambu, sedangkan penutup atap pada tongkonan kedua berbahan dasar logam, yaitu seng gelombang.

Ketiga, alang yang baru saja dipugar adalah alang yang bernomor urut satu, yakni alang yang lokasinya paling dekat dengan pintu masuk ke wilayah permukiman Situs Nanggala, sedangkan alang kedua sampai dengan keenambelas memiliki kondisi yang bervariasi, ada yang berkondisi baik sampai dengan kondisi sedang. Keempat, pada bagian tepi utara batas permukiman Situs Nanggala terdapat banyak rumpun bambu. Rumpun-rumpun bambu ini menjadi habitat atau tempat tinggal bagi kelelawar yang berjumlah amat banyak. Secara skematis, Situs Nanggala disajikan dalam Gambar 5.

\subsection{Hasil Identifikasi Kayu.}

\subsubsection{Kayu bahan komponen tiang}

Untuk mengidentifikasi kayu yang menjadi bahan pembuatan komponen tiang Alang, disajikan dua foto makroskopis penampang melintang sampel kayu arkeologis dan kayu baru dengan perbesaran 10 X. Keduanya disajikan berurutan pada gambar 6 dan 7 berikut.

Hasil pengamatan mengenai ciri-ciri struktur kayu terhadap penampang melintang makroskopis sampel

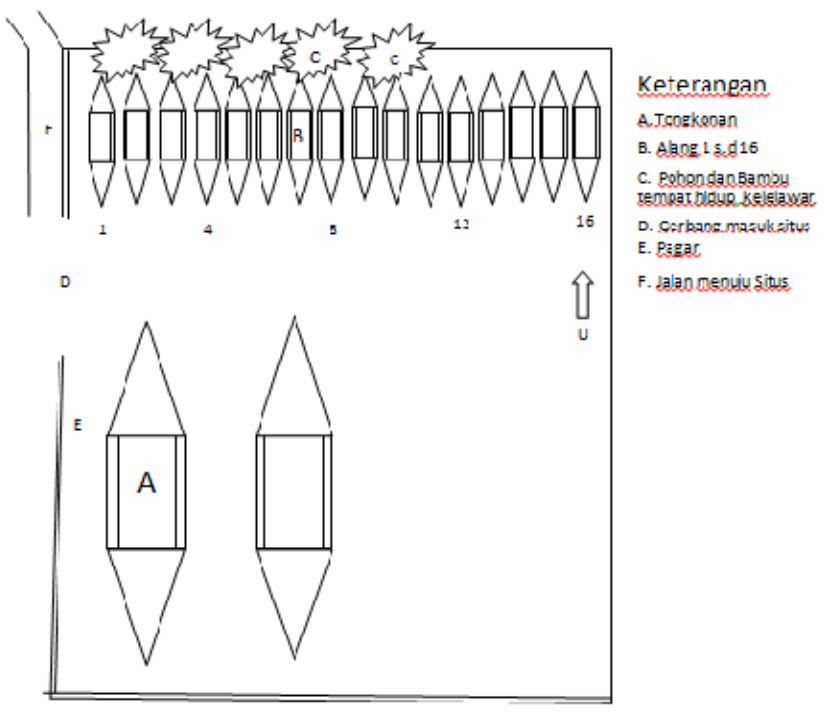

Gambar 5. Denah Tongkonan Alang Situs Nanggala 


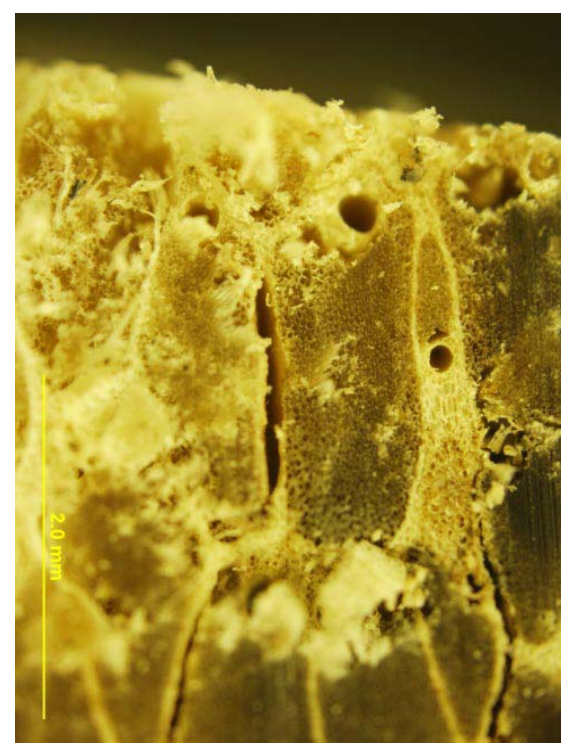

Gambar 6. Penampang melintang kayu arkeologis komponen tiang Alang

kayu baru pada gambar 7 dapat dideskripsikan sebagai berikut:

a. Lingkaran tahun tidak ada pada kayu ini.

b. Memiliki sistem pembuluh yang terdiri atas xylem dan phloem.

c. Memiliki sarung sklerenkim berupa berkas-berkas serabut yang besar, sangat rapat dan padat. Sarung sklerenkim ini mengelilingi dan melindungi sistem pembuluh.

d. Jaringan parenkim merupakan jaringan dasar yang menyelimuti sistem pembuluh dan jaringan sklerenkim.

Berdasarkan deskripsi ciri-ciri struktur kayu tersebut, maka determinasi mengarahkan bahwa sampel kayu baru tergolong di dalam kelas monokotiledoneae. Pada tahap ini, determinasi berpindah dari aras internal kayu menuju ke aras eksternal kayu, yakni berdasar morfologi pohon. Berdasarkan penampilan tiang pada alang yang secara morfologis merupakan suatu batang pohon yang berbentuk silinder dan tidak memiliki ruas (nodia), tetapi memiliki ukuran diameter yang relatif besar maka determinasi di dalam kelas monokotiledoneae ini mengarahkan lebih lanjut kepada ordo palmae. Berdasarkan informasi lebih lanjut bahwa permukaan batang ini sangat licin tetapi memiliki banyak duri yang tajam dan tersusun secara rapat, dan bahwa pelepah daun pohon ini juga banyak berduri, maka determinasi di dalam ordo palmae ini menyimpulkan bahwa kayu ini berasal

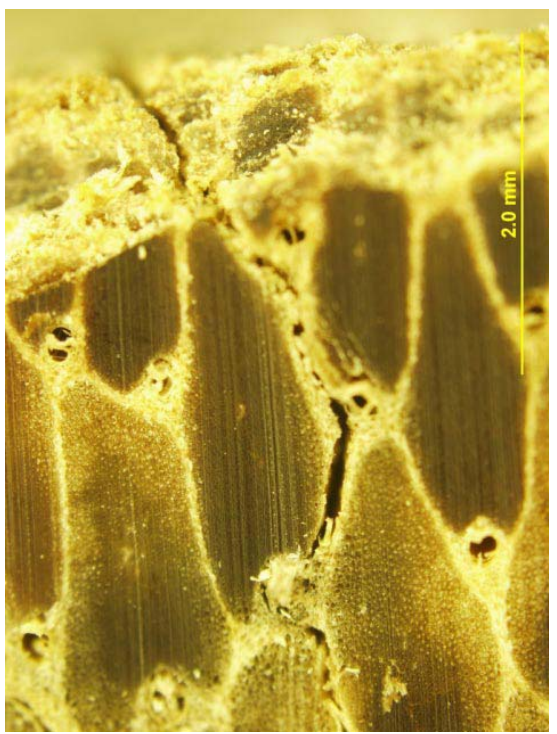

Gambar 7. Penampang melintang kayu baru komponen tiang Alang

dari jenis yang nama ilmiahnya Pigafetta fillaris Giseke (1792). Pada tahun 1977, namanya berganti menjadi Pigafetta filifera Merr, (Giusuppe, tanpa tahun).

Hibitus pohon Pigafetta yang disertai dengan diskripsi morfologis sebagaimana disebutkan sangat bersesuaian dengan foto yang disajikan dalam laman (website) beralamatkan http:/ /www.pacsoa.org.au/palms/ Pigafetta/cultivation.html. (Anonim, tanpa tahun). Foto di dalam laman tersebut memang menunjuk pada nama Pigafetta. Nama perdagangan kayu Pigafetta adalah Wanga (Anonim, 1995).

Sementara itu, hasil pengamatan ciri-ciri struktur kayu terhadap penampang melintang makroskopis sampel kayu arkeologis pada Gambar 6 mendapatkan hasil diskripsi yang tidak berbeda dengan hasil diskripsi kayu baru pada Gambar 7. Oleh karena itu, kayu arkeologis sebagai bahan tiang juga berjenis Pigafetta filifera Merr atau kayu Wanga (Anonim, 1995).

\subsubsection{Kayu bahan komponen balok}

Untuk mengidentifikasi kayu yang menjadi bahan pembuatan komponen balok pada alang, disajikan dua foto makroskopis penampang melintang sampel kayu arkeologis dan kayu baru dengan perbesaran $10 \mathrm{x}$. Masing-masing disajikan berurutan pada Gambar 8 dan 9 berikut. 


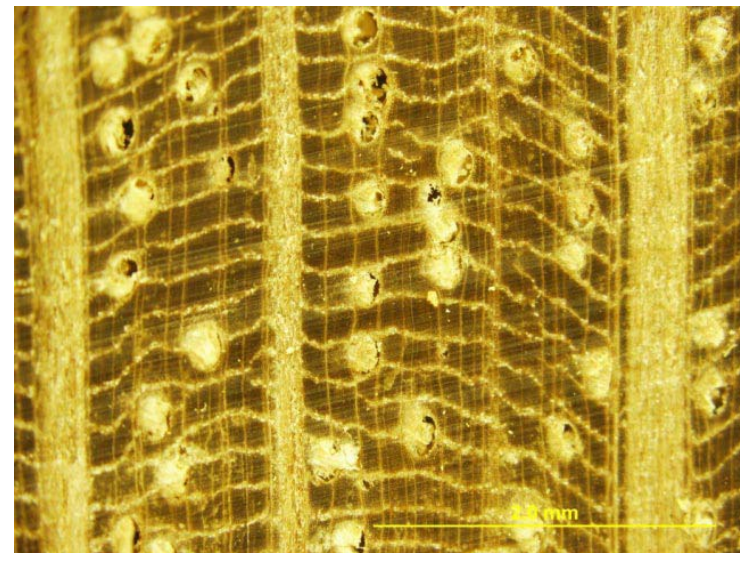

Gambar 8. Foto penampang melintang kayu arkeologis komponen balok Alang

Hasil pengamatan mengenai ciri-ciri struktur kayu terhadap penampang melintang makroskopis sampel kayu arkeologis pada gambar 8 dapat dideskripsikan sebagai berikut.

a. Lingkaran tahun tampak secara tidak begitu jelas. Kenampakannya terlihat dari perbedaan dimensi komponen struktur kayu pada bagian kayu awal dan kayu akhir.

b. Pembuluh berpenyebaran tunggal, tidak mengelompok, tidak dalam baris radial, juga tidak dalam baris tangensial. Pembuluh tersusun di dalam susunan tata baur.

c. Parenkim bertipe paratrakheal (parenkim yang bersinggungan dengan pembuluh) dan apotrakheal (parenkim yang tidak berhubungan dengan pembuluh) ada pada kayu. Parenkim paratrakheal meliputi parenkim vasisentrik (yaitu parenkim yang menyelubungi secara penuh terhadap pembuluh) dan abaksial (yaitu parenkim yang menyelubungi secara tidak penuh terhadap pembuluh). Di samping itu, juga terdapat parenkim apotrakheal berupa parenkim bentuk pita kecil yang berukuran panjang.

d. Jari-jari pada penampang melintang tampak oleh mata telanjang sebagai jari-jari yang tidak homogen, karena ada jari-jari yang berukuran kecil dan ada juga yang berukuran sangat besar. Pada Gambar 3 terlihat ada tiga jari-jari besar pada penampang melintang.

e. Kayu ini memiliki tekstur yang agak kasar.

f. Serat pada kayu ini memiliki arah yang tidak lurus dan sedikit miring.

g. Saluran damar tidak terdapat pada kayu.

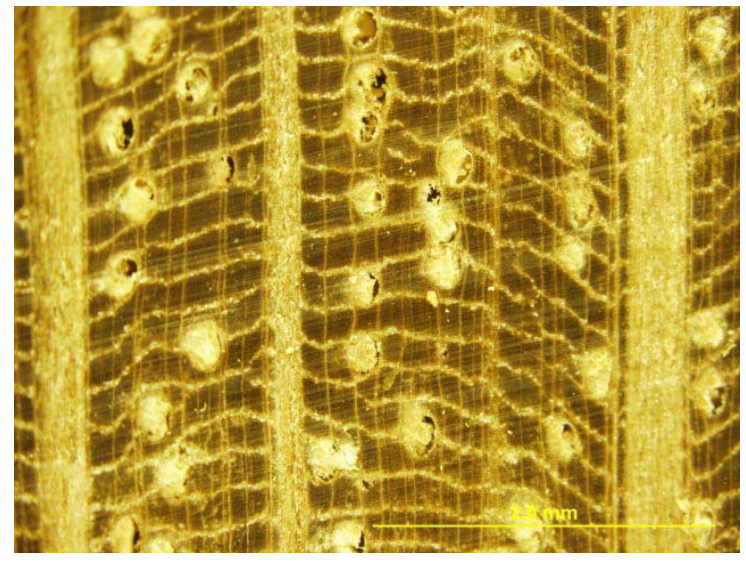

Gambar 9. Foto penampang melintang kayu baru komponen balok Alang

Berdasarkan deskripsi ciri-ciri struktur kayu tersebut, maka aktivitas determinasi menyimpulkan bahwa sampel kayu arkeologis adalah genus Casuarina dan spesies junghubniana, sehingga nama ilmiahnya adalah Casuarina junghubniana Miq. Kesimpulan ini diperkuat oleh adanya perbedaan mengenai dimensi dan persebaran pembuluh antara spesies kayu ini terhadap spesies kayukayu Casuarina yang lain, yakni: Casuarina cunninghamiana, Casuarina oligodon, Casuarina papuana, Casuarina stricta, Casuarina sumatrana, yang masing-masing disajikan secara berurutan oleh Ilic (1991) pada gambar nomor: 180, 181, 182, 183, dan 186, maupun terhadap spesies Casuarina equisetifolia yang disajikan oleh Hayashi dkk (1973) pada gambar nomor 26. Casuarina junghubniana Miq juga disebut Casuarina montana Leschen ex Miq (Procea, 1993). Jenis kayu ini dikenal dengan nama perdagangan cemara gunung (Anonim, 1976).

Sementara itu, hasil pengamatan mengenai ciri-ciri struktur kayu terhadap penampang melintang makroskopis sampel kayu baru pada gambar 9 mendapatkan hasil diskripsi yang tidak berbeda dengan hasil diskripsi kayu arkeologis pada gambar 8. Oleh karena itu, kayu baru sebagai bahan balok juga berjenis Casuarina junghubniana Miq.

\subsubsection{Kayu bahan papan lantai}

Untuk mengidentifikasi kayu yang menjadi bahan pembuatan komponen papan lantai alang, disajikan foto-foto makroskopis penampang melintang sampel kayu arkeologis dan kayu baru dengan perbesaran $10 \mathrm{x}$. Masing-masing disajikan berurutan pada gambar 10 dan 11 


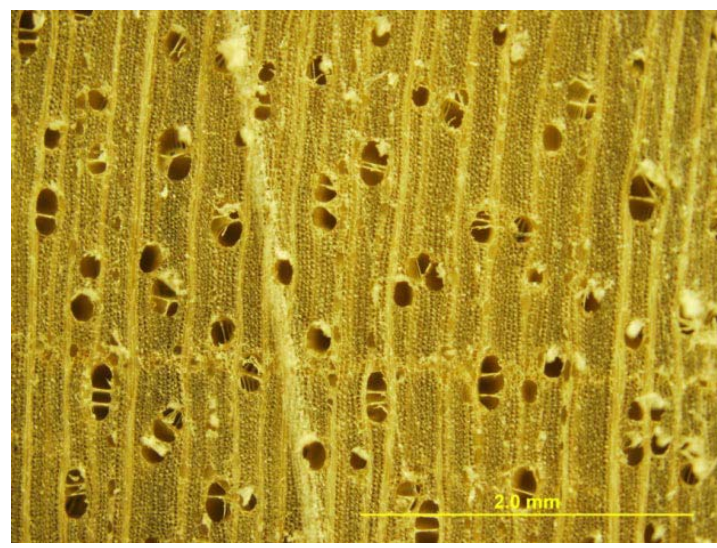

Gambar 10. Foto penampang melintang kayu arkeologis komponen papan lantai Alang

Hasil pengamatan mengenai ciri-ciri struktur kayu terhadap penampang melintang makroskopis sampel kayu arkeologis pada gambar 10 dapat dideskripsikan sebagai berikut.

a. Lingkaran tahun tampak secara jelas. Kenampakannya ditandai oleh parenkim terminal atau parenkim bentuk pita.

b. Pembuluh berpenyebaran tunggal dan berganda 2 sampai dengan 3. Pembuluh bersusunan tata lingkar sejati.

c. Parenkim bertipe paratrakheal (parenkim yang bersinggungan dengan pembuluh) dan apotrakheal (parenkim yang tidak berhubungan dengan pembuluh) ada pada kayu. Parenkim paratrakheal meliputi parenkim abaksial (yaitu parenkim yang menyelubungi secara tidak penuh terhadap pembuluh). Di samping itu juga terdapat parenkim apotrakheal berupa parenkim bentuk pita kecil yang berukuran pendek.

d. Jari-jari pada penampang melintang tampak oleh mata sebagai jari-jari yang tidak homogen, karena ada jarijari berukuran kecil dan yang berukuran agak besar.

e. Kayu ini memiliki tekstur agak halus.

f. Serat pada kayu ini memiliki arah yang lurus.

g. Saluran damar tidak terdapat pada kayu.

Berdasarkan diskripsi ciri-ciri struktur kayu tersebut, maka aktivitas determinasi menyimpulkan bahwa sampel kayu arkeologis adalah Elmerrillia ovalis Dandy. Kesimpulan ini diperkuat oleh adanya kesesuaian antara foto makroskopis kayu arkeologis ini dengan foto makroskopis yang terdapat pada halaman 36 buku Atlas Kayu Indonesia jilid III (Abdulrrohin dkk, 2004) maupun foto nomor 661 di dalam buku Csiro Atlas of

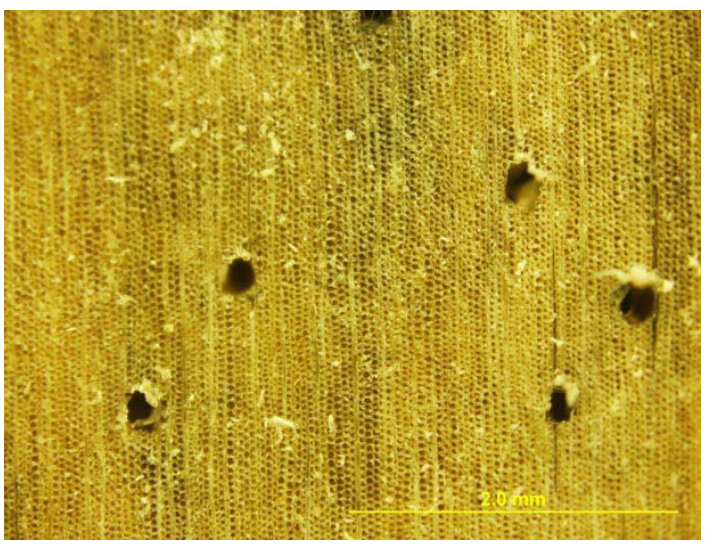

Gambar 11. Foto penampang melintang kayu baru komponen papan lantai Alang

Hardwood (Ilic, 1991). Kedua foto ini menunjuk pada jenis kayu Elmerrillia ovalis Dandy. Jenis kayu ini dikenal dengan nama perdagangan cempaka hutan (Abdulrrohim $\mathrm{dkk}, 2004)$.

Sementara itu, hasil pengamatan mengenai ciri-ciri struktur kayu terhadap penampang melintang makroskopis sampel kayu baru pada Gambar 11 mendapatkan hasil deskripsi sebagai berikut:

a. Lingkaran tahun tidak tampak.

b. Pembuluh tidak terdapat pada kayu.

c. Saluran damar terdapat pada kayu. Saluran damar berpenyebaran tunggal.

d. Parenkim bertipe epithel dan parenkin ini membentuk saluran damar.

e. Jari-jari memiliki satu macam ukuran dan berukuran kecil.

f. Kayu ini memiliki tekstur agak halus.

g. Serat pada kayu ini memiliki arah yang lurus.

Berdasarkan deskripsi ciri-ciri struktur kayu tersebut, maka aktivitas determinasi menyimpulkan bahwa sampel kayu arkeologis adalah Pinus merkusii Junghuhn et de Vries. Kesimpulan ini diperkuat oleh adanya kesesuaian antara foto makroskopis kayu ini dengan foto makroskopis yang terdapat pada halaman 42 buku Atlas Kayu Indonesia jilid II (Martawijaya dkk, 1989), dan foto pada halaman 351 buku PROSEA jilid 5 (Soerianegara dan Lemmens, 1993). Jenis kayu ini dikenal dengan nama perdagangan tusam (Martawijaya $\mathrm{dkk}, 1989)$.

Berdasarkan kedua hasil identifikasi tersebut, dapat disimpulkan bahwa ada perbedaan jenis kayu arkeologis dan kayu baru yang digunakan sebagai bahan 
papan lantai. Kayu arkeologis berjenis Elmerrillia ovalis Dandy, sedangkan kayu baru berjenis Pinus merkusii Junghuhn et de Vries.

\subsubsection{Kayu bahan papan dinding}

Untuk mengidentifikasi kayu yang menjadi bahan pembuatan komponen papan dinding pada alang, disajikan foto makroskopis penampang melintang sampel kayu arkeologis dan kayu baru berpembesaran $10 \mathrm{x}$. Masing-masing disajikan berurutan pada Gambar 12 dan 13.

Hasil pengamatan mengenai ciri-ciri struktur kayu terhadap penampang melintang makroskopis sampel kayu arkeologis pada gambar 12 mendapatkan hasil diskripsi yang sama dengan diskripsi kayu pada gambar 10. Oleh karena itu, kayu arkeologis sebagai penyusun papan dinding alang juga berjenis Elmerrillia ovalis Dandy.

Sementara itu, hasil pengamatan mengenai ciri-ciri struktur kayu terhadap penampang melintang makroskopis sampel kayu baru pada gambar 8 mendapatkan hasil deskripsi sebagai berikut:

a. Lingkaran tahun tidak tampak secara jelas.

b. Pembuluh berpenyebaran tunggal dan berganda radial

2 sampai dengan 3. Pembuluh bersusunan tata baur.

c. Parenkim bertipe paratrakheal dan apotrakheal ada pada kayu. Parenkim paratrakheal meliputi parenkim vasisentrik (yaitu parenkim yang menyelubungi secara penuh terhadap pembuluh), sedangkan parenkim apotrakheal berupa parenkim diffus.

d. Jari-jari pada penampang melintang tampak oleh mata sebagai jari-jari yang tunggal dan homogen, yakni jari-

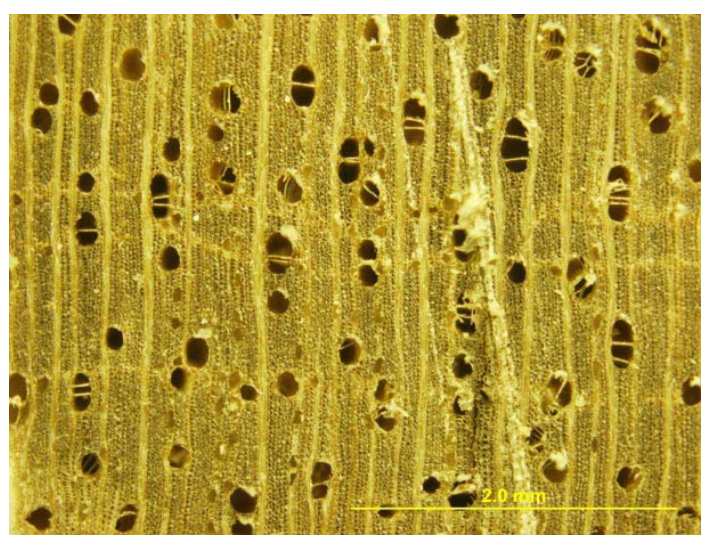

Gambar 12. Foto penampang melintang kayu arkeologis komponen papan dinding Alang jari berukuran kecil.

e. Kayu ini memiliki tekstur agak kasar.

f. Serat pada kayu ini memiliki arah yang berpadu.

g. Saluran damar tidak terdapat pada kayu.

Berdasarkan deskripsi ciri-ciri struktur kayu tersebut, maka aktivitas determinasi menyimpulkan bahwa sampel kayu arkeologis adalah Paraserianthes falcataria (L) Nielson. Kesimpulan ini diperkuat oleh adanya kesesuaian antara foto makroskopis kayu ini dengan tiga foto makroskopis yang terdapat tiga sumber pustaka, yaitu foto pada halaman 62 buku Atlas Kayu Indonesia jilid II (Martawijaya dkk, 1989), maupun foto pada halaman 321 buku PROSEA jilid 5 (Soerianegara dan Lemmens, 1993) serta foto nomor 2035 di dalam buku Csiro Atlas of Hardwood (llic, 1991). Ketiga foto ini menunjuk pada jenis kayu Paraserianthes falcataria (L) Nielson. Jenis kayu ini dikenal dengan nama perdagangan jeunjing atau sengon (Martawijaya dkk, 1989).

Berdasarkan kedua hasil identifikasi tersebut, dapat disimpulkan bahwa ada perbedaan jenis kayu arkeologis dan kayu baru yang digunakan sebagai bahan papan dinding alang. Kayu arkeologis berjenis Elmerrillia ovalis Dandy, sedangkan kayu baru berjenis Paraserianthes falcataria (L) Nielson.

\subsubsection{Bahan penutup atap alang}

Proses evaluasi terhadap bahan arkeologis maupun bahan baru yang difungsikan sebagai penutup atap alang dapat dilakukan dengan cara yang sangat mudah tanpa menggunakan bantuan mikroskop. Hal ini disebabkan karena perbedaan antara keduanya sangat mencolok dan kasat mata. Bahan arkeologis sebagai

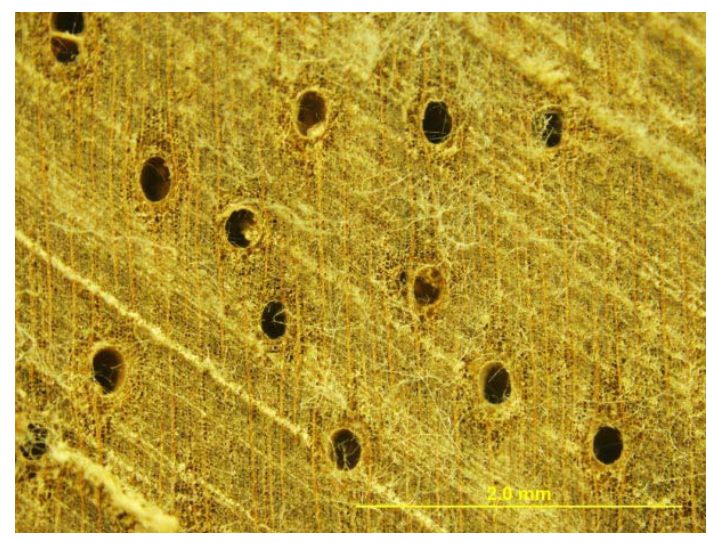

Gambar 13. Foto penampang melintang kayu baru komponen papan dinding Alang 
penutup atap alang adalah bambu, sedangkan bahan baru sebagai penggantinya adalah bahan logam yang berupa seng gelombang. Oleh karena itu, perbedaan antara bahan arkeologis dan bahan baru bagi penutup atap tidak hanya berada dalam aras jenis bahan, melainkan berbeda dalam aras asal dan komposisi bahan. Dalam konteks ini, bahan arkeologis penutup atap alang berasal dari bahan organik, sedangkan bahan baru penutup atap alang tersebut berasal dari bahan anorganik dengan jenis logam.

\section{Kesimpulan dan Saran}

Hasil penelitian menyimpulkan tiga hal. Pertama, seluruh komponen struktural maupun nonstruktural bangunan alang nomor satu telah diganti dengan jenis kayu baru, bahkan dengan bahan yang baru. Kedua, identifikasi terhadap kayu (bahan) arkeologis dan kayu (bahan) baru secara berurutan menghasilkan jenis berikut: (a) kayu banga (Pigafetta filifera Merr) dan juga kayu banga bagi komponen tiang, (b) kayu cemara gunung (Casuarina Junghubniana Miq) dan juga cemara gunung bagi balok, (c) kayu uru (Elmerrillia ovalis Dandy) dan kayu tusam (Pinus

\section{DAFTAR PUSTAKA}

Abdurrohim. S, Mandang, Y.I., Sutisna U., (editor). 2004. Atlas Kayu Indonesia. Jilid III. Lembaga Penelitian dan Pengembangan Kehutanan, Departemen Kehutanan. Bogor.

Akbar, A, 2010. Arkeologi Masa Kini. Alqaprint Jatinangor. Balai Arkeologi Bandung. Bandung.

Anonim, 1976. Vademecum Kehutanan Indonesia. Direktorat Jenderal Kehutanan. Departemen Pertanian. Jakarta

Anonim, 1995. Daftar Nama dan Sifat-sifat Kayu Perdagangan yang tumbuh di Pulau Sulawesi. Balai Penelitian Kehutanan Provinsi Sulawesi Selatan.

Anonim, 2009. Tana Toraja Traditional Settlement. Unesco. Sumber http://whc.unesco.org/en/ tentativelists/5462/ Diunduh 21 Januari 2013. merkusii Junghuh et de Vries) bagi papan lantai (d) kayu uru dan kayu sengon (Paraserianthes falcataria Nielson) bagi papan dinding, (e) bambu apus dan seng gelombang bagi penutup atap. Ketiga, pemugaran alang dilakukan tanpa disertai dengan ketaatan penuh terhadap penerapan prinsip-prinsip arkeologis, khususnya prinsip orisinalitas jenis bahan.

Oleh karena itu, perlu disarankan kepada semua pihak, bahwa apabila pemugaran terhadap suatu bangunan alang sebagai cagar budaya berbahan kayu harus dilakukan, maka pelaksanaan pemugaran itu wajib dilakukan dengan penerapan sepenuhnya prinsip-prinsip arkeologis, antara lain prinsip untuk mempertahankan orisinalitas jenis kayu sebagai bahan bangunan. Apabila prinsip ini tidak ditaati, maka status cagar budaya bagi bangunan ini tidak dapat lagi dipertahankan, bahkan kondisi ini dapat dijadikan sebagai salah satu alasan bagi UNESCO untuk tidak mengabulkan pengusulannya sebagai warisan dunia (Wold heritage).

Anonim, 2011. Arsitektur Rumah Toraja. Sumber: http://wartawarga.gunadarma.ac.id/2011/05/ arsitektur-rumah-toraja. Diunduh 22 Agustus 2011.

Anonim (tanpa tahun). Pigafetta fillaris Cultification. Dalam http://www.pacsoa.org.au/palms/ Pigafetta/cultivation.html Diunduh pada 8 Juli 2011

Giusuppe Mazza (tanpa tahun). Pigafetta fillaris. Dalam http: / / www.photomazza.com/?Pigafettafilaris\&lang= Diunduh pada 8 Juli 2011.

Hayashi, S., Kishima, T., Lau L.C., Wong T.M., and Menon, P.K.B., 1973. Micrographic Atlas of Southeast Asian Timber. Division of Wood Biology, Wood Research Institute, Kyoto University. Kyoto. Japan. 
Ilic, J. 1991. CSIRO Atlas of Hardwood. Crawfor House Press. Melbourne. Australia.

Inajati, 2009. Paradoks Kawasan Budaya: Studi tentang Strategi Pengelolaan Saujana Budaya di Tengah Industri Pariwisata dan World Heritage di Toraja Utara. Laporan Penelitian Hibah Kompetensi Tahap I Tahun 2010. Fakultas Ilmu Budaya, Universitas Gadjah Mada, Yogyakarta.

Martawijaya, A., Kartasujana, I., Mandang, Y.I., Prawira, Kadir, K., 1989. Atlas Kayu Indonesia. Jilid II. Lembaga Penelitian dan Pengembangan Kehutanan, Departemen Kehutanan. Bogor.

Presiden Republik Indonesia, 2010. Undang-undang Republik Indonesia Nomor 11 tahun 2010 tentang Cagar Budaya. Lembaran Negara Republik Indonesia.
Procea, 1993. Agroforestry Tree Database: Species Information, Casuarina junghuhniana. World Agroforestry Centre, ICRAF (International Centre for Research in Agroforestry). Sumber: http: / / www.worldagroforestrycentre.org/ sea/products/afdbases/af/asp/SpeciesInfo. asp?SpID=481. Diunduh 5 Oktober 2012.

Soenardi, 1977. Ilmu Kayu. Yayasan Pembina Fakultas Kehutanan, Universitas Gadjah Mada. Yogyakarta.

Soerianegara, I., dan Lemmens RHMJ. (editor), 1993. Plant Resources of South-East Asia (PROSEA). No 5 (1). Pudoc Scientific Publishers. Wageningen. 